\title{
Critical care considerations in the management of the trauma patient following initial resuscitation
}

\author{
Roger F Shere-Wolfe*, Samuel M Galvagno Jr and Thomas E Grissom
}

\begin{abstract}
Background: Care of the polytrauma patient does not end in the operating room or resuscitation bay. The patient presenting to the intensive care unit following initial resuscitation and damage control surgery may be far from stable with ongoing hemorrhage, resuscitation needs, and injuries still requiring definitive repair. The intensive care physician must understand the respiratory, cardiovascular, metabolic, and immunologic consequences of trauma resuscitation and massive transfusion in order to evaluate and adjust the ongoing resuscitative needs of the patient and address potential complications. In this review, we address ongoing resuscitation in the intensive care unit along with potential complications in the trauma patient after initial resuscitation. Complications such as abdominal compartment syndrome, transfusion related patterns of acute lung injury and metabolic consequences subsequent to post-trauma resuscitation are presented.
\end{abstract}

Methods: A non-systematic literature search was conducted using PubMed and the Cochrane Database of Systematic Reviews up to May 2012.

Results and conclusion: Polytrauma patients with severe shock from hemorrhage and massive tissue injury present major challenges for management and resuscitation in the intensive care setting. Many of the current recommendations for "damage control resuscitation" including the use of fixed ratios in the treatment of trauma induced coagulopathy remain controversial. A lack of large, randomized, controlled trials leaves most recommendations at the level of consensus, expert opinion. Ongoing trials and improvements in monitoring and resuscitation technologies will further influence how we manage these complex and challenging patients.

Keywords: Coagulopathy, Trauma, Acute lung injury, Transfusion, Intensive care unit, Complications, Thromboelastography

\section{Introduction}

Resuscitation of the severely injured patient is a topic of ongoing evolution and controversy. Since the early 1990's, management of critically ill polytrauma patients has been governed by the "damage control" paradigm first introduced in abdominal surgery [1] and subsequently expanded to most areas of care, including orthopedic [2], vascular [3] and thoracic injuries [4]. According to one definition, damage control surgery (DCS) is the "planned temporary sacrifice of normal anatomy to preserve vital physiology"[5]. Because severely injured patients are too physiologically deranged to tolerate prolonged definitive repair, initial surgical intervention is limited to minimally necessary

\footnotetext{
* Correspondence: rsherewolf@mac.com

University of Maryland School of Medicine, R Adams Cowley Shock Trauma Center, 22 S. Greene St, Ste. T1R77, Baltimore, MD 21201, USA
}

stabilization and control of hemorrhage. Thus, the patient presenting to the intensive care unit (ICU) following initial resuscitation and DCS may be far from stable with ongoing hemorrhage, resuscitation needs, and injuries still requiring definitive repair.

Care of the polytrauma patient does not end in the operating room or resuscitation bay. As one authority has noted, "the best place for a sick person is in the ICU"[6]. ICU physicians must be prepared to receive patients at any point along the continuum of care, and must be adept at assessing the patient's physiologic status and addressing ongoing needs in a prompt and expeditious fashion. As the patient stabilizes, the ICU physician must then begin to transition the focus of care to longer term considerations such as potential for infectious and thromboembolic complications, organ support, and the need for planned re-exploration and staged definitive repair. 
Although much focus has been placed on the initial management of the traumatized patient, the transition between early resuscitation of the critically injured patient with hemorrhage and/or polytrauma and the ICU has received less attention. These patients pose a number of unique challenges for the ICU physician including the need for ongoing resuscitation, determination of resuscitation endpoints, and management of early postresuscitation complications. How well these are addressed may have critical implications for long-term outcome and survival. In this review, we will address early ICU considerations in the polytrauma patient requiring aggressive early resuscitation. While no consensus definition for "polytrauma" has been recognized, generally accepted definitions use an Injury Severity Score (ISS) of greater than 15 to 17 or an Abbreviated Injury Scale (AIS) of greater than 2 in at least two body regions [7].

\section{Continued resuscitation in the ICU}

\section{Immediate assessment and basic physiologic support}

Upon arrival to the ICU it is essential for the ICU physician to understand where the patient is in the continuum of both surgical management and ongoing resuscitation (Figure 1), and to assess overall stability and the extent of unresolved shock. Because shock is a cumulative phenomenon in which the depth and duration determine the total "dose" in an integrative fashion [8], the timeliness of resuscitation may have a significant impact on subsequent morbidity and mortality (Figure 2) [9]. Virtually all critically injured patients require some degree of immediate physiologic support on arrival to the ICU. This includes assurance of adequate respiratory and ventilator support as well as aggressive intervention to minimize secondary central nervous system (CNS) injury, resolve critical acid-base and electrolyte disorders and restore normothermia.

Volume loading remains the mainstay of circulatory support. Vasopressors seldom improve microvascular perfusion and may mask underlying shock so their early role in the resuscitation of the trauma should generally be cautioned [10]. Patients requiring vasopressors are often either severely physiologically perturbed or underresuscitated, and their lack of response to fluid therapy may be suggestive of irreversible shock. There has been some recent support for the use of low-dose vasopressin to treat underlying deficiency and decrease overall fluid requirements [11-13] though this is not universally accepted, and may impair the micro-circulation and produce splanchnic ischemia [14]. Patients with concomitant CNS injuries may require vasopressor support to counteract spinal shock, or to maintain cerebral perfusion in the setting of traumatic brain injury (TBI).

Respiratory support must continue to ensure adequate oxygenation and ventilation. Inadequate oxygen delivery only worsens tissue hypoperfusion. This may be especially deleterious in cases with concomitant CNS injury [15]. Respiratory acidosis superimposed on metabolic acidosis may also be extremely detrimental. The use of positive end-expiratory pressure and open lung ventilation techniques in the hypovolemic patient can increase intrathoracic pressure and may critically impede venous return resulting in profound hypotension. Physiologically deranged patients often present to the ICU with profound metabolic acidosis and hypothermia. These impair both hemodynamic and hemostatic function. Hypothermia should be corrected aggressively with full body passive or active re-warming. Metabolic acidosis predicts both mortality and transfusion needs [16,17], and is generally best treated by restoration of tissue perfusion. Massive fluid shifts often produce profound

$$
\downarrow
$$

Prehospital phase

Recognition

Identify cause

Correct mechanical causes

Basic source control

"Damage Control" with controlled resuscitation

\section{Late Aggressive resuscitation -Macrocirculatory stability -Restore blood volume -Correct coagulopathy and physiologic derangement -Restore homeostasis \\ Further source control and selective definitive repair \\ Evaluate \\ Further resuscitation \\ Re-evaluate}

Supportive and long-term care

Figure $1 \mathrm{~A}$ general approach to early versus late resuscitation. 
electrolyte disturbances, which should also be promptly corrected.

Polytrauma patients with concomitant CNS injuries pose an especially great challenge. Even mild TBI can blossom into a life-threatening condition when compounded by hypoxia and hypotension [15]. Prevention of secondary injury should be among the highest priories in any patient with evidence or suspicion of CNS injury [18]. CNS assessment and/or monitoring should be instituted at the earliest possible juncture.

\section{Assessment of hemostasis and correction of coagulopathy}

Cessation of bleeding, whether surgical or medical, is the sine qua non of resuscitation from injury. There is little utility in targeting endpoints of resuscitation in the face of ongoing hemorrhage. Life-threatening coagulopathy is one of the most serious complications of patients in profound shock from massive hemorrhage, and is generally predictable at an early stage [19]. Increased early transfusion requirements are also generally predictive of subsequent organ dysfunction [20-22]. Studies have shown that ongoing coagulopathy on admission to the ICU is independently associated with both an increase in morbidity and 30-day mortality [23].

The majority of trauma patients initially present with normal or prothrombotic coagulation profiles. However, those most seriously injured are likely to present with evidence of hypocoagulability, accelerated fibrinolysis, or both $[24,25]$. Upon transfer to the ICU the patient's coagulation status may be in any of these states. It is essential therefore to promptly re-assess the patient's coagulation status in order to initiate appropriate therapy. "Standard" laboratory tests such as prothrombin time (PT), partial thromboplastin time (PTT), international normalized ratio (INR), fibrinogen level and platelet count are still the most common coagulation assays in clinical use, despite considerable evidence that they provide an extremely incomplete picture of in vivo hemostasis [26,27], that they are poor predictors of clinical bleeding [28], and that they do not provide an adequate basis for rational targeted hemostatic resuscitation [29,30]. Although significantly elevated admission PT and PTT levels are predictive of increased mortality from injury [31], there is little evidence that they provide a realistic target for resuscitation. Moderately elevated values may have little clinical significance, and correction to "normal" values may require large amounts of resuscitation fluids, especially fresh frozen plasma (FFP). In the absence of active clinical bleeding, attempts to normalize laboratory values have the potential to introduce transfusion- and volume-related complications

These deficiencies underscore the need for reliable point-of-care hemostatic monitoring with clinical relevance in situations of generalized coagulopathy due to massive hemorrhage. There is increasing evidence that viscoelastic monitoring technologies such as $\mathrm{TEG}^{\circledR}$ (Haemonetics Corp., Niles, IL, USA) and ROTEM ${ }^{\circledR}$ (Tem Innovations GmbH, Munich, Germany) are superior for detecting clinically relevant hemostatic abnormalities in trauma and surgical patients with massive bleeding and diffuse coagulopathy [32,33]. Viscoelastic monitoring has been much more widely used in Europe than in the United States, for both intra-operative and ICU management of bleeding surgical and trauma patients. Schöchl and colleagues have

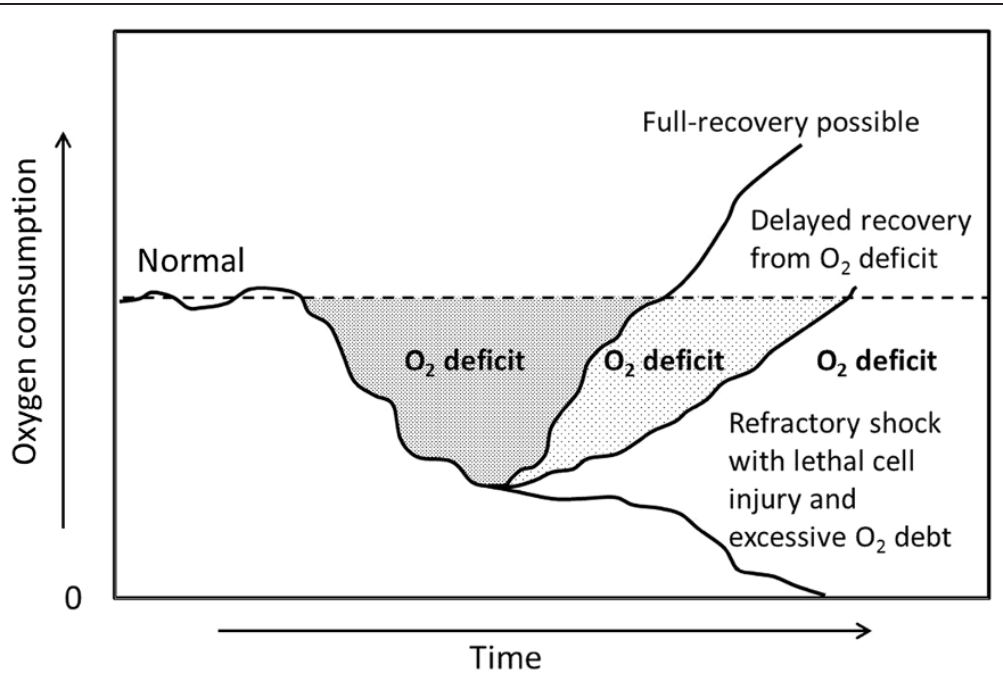

Figure 2 Prolonged tissue hypoperfusion creates a cumulative "oxygen debt" directly related to the "dose" of shock, based on both the duration and depth of hypoperfusion. Eventually this results in irreversible disruption of homeostasis such that patients will not respond to resuscitative efforts even after the initial insults have been corrected [adopted from [9]]. 
recently published a detailed review on the use of viscoelastic monitoring targeted resuscitations [34]. It should also be noted that both viscoelastic and standard coagulation tests are generally performed after warming specimens to $37^{\circ} \mathrm{C}$, and do not reflect the potentially considerable effects of hypothermia on in vivo hemostasis [35].

Because of evidence that severely injured trauma patients are likely to develop an early and aggressive endogenous coagulopathy separate from later loss and dilution of clotting factors compounded from hypothermia and acidosis [31,36-41], the practice of "hemostatic" resuscitation has become commonplace in the most severely injured patients. This entails the early and aggressive use of hemostatic products combined with red blood cells as the primary resuscitation fluids in order to avoid rapid deterioration into the "bloody vicious cycle" and the classic "lethal triad" of hypothermia, acidosis and coagulopathy [42]. Two very distinct paradigms of hemostatic resuscitation have currently emerged: the damage control resuscitation (DCR) model, which uses pre-emptive administration of empiric ratios of blood and hemostatic products to approximate whole blood, often according to an established institutional "massive transfusion protocol" [43-47]; and goal-directed hemostatic resuscitation approaches (also often protocol-based), which generally use point-of-care viscoelastic monitoring (Figure 3) combined with the prompt administration of hemostatic concentrates [24,26,27,34]. Regardless, it is highly likely that the patient with massive hemorrhage who arrives to the ICU underresuscitated with a coagulopathy has been managed according to some sort of hemostatic resuscitation approach which should be continued in the ICU until it is clear that hemostasis has been achieved. It is beyond the scope of this review to discuss the relative merits of these two approaches in detail, however, the critical care provider should communicate with the trauma and operative team to see where the patient is in terms of their hemostatic resuscitation.

With DCR, large volumes of fresh frozen plasma are frequently administered as part of the hemostatic resuscitation and this aggressive use of FFP may be continued into the ICU setting. This aggressive use of FFP may substantially increase the risks of adverse complications. One study attempting to correct the INR to 1.3 in the ICU documented a high rate of severe ARDS $[48,49]$. Isolated PT/INR levels are poor predictors of clinical bleeding in trauma patients, and thrombin generation is generally preserved or even increased after significant blood loss because of dysregulation, with loss of clotting factors balanced by loss of regulatory inhibitors [50]. If FFP is being used as the primary hemostatic resuscitation fluid and viscoelastic monitoring is not available, the ICU physician should generally accept an INR in the 1.5-1.7 range provided there is no evidence of active bleeding. This INR target is based on studies demonstrating a limited ability of FFP transfusions to normalize coagulation test results with an INR $<1.7$ [51].

Recombinant activated factor VIIa (rFVIIa) has found considerable off-label use in the management of refractory coagulopathy in hemorrhagic shock/trauma patients. Although initially touted as a "total hemostatic agent", it now seems clear that rFVIIa acts mainly as a potent thrombin generator [52]. High dose rFVIIa (usually $>=80-90 \mu \mathrm{g} / \mathrm{kg}$ ) works predominantly by a direct effect on activated platelets rather than via its higher affinity binding to tissue factor [53]. Because tissue factor is expressed by inflammatory cells, there is significant potential for systemic micro-thrombi generation, and several studies have shown a risk of thrombotic complications on the order of 5-7\% [54]. Efficacy of rFVIIa is dependent on the presence of adequate substrate for clot formation such as fibrinogen and platelets, and may be significantly impaired under acidotic conditions [55]. Because of these considerations, the use of high dose rFVIIa as rescue therapy in refractory hemorrhagic shock is controversial, and should be undertaken with caution. The ICU physician should be aware that patients who have received rFVIIa during their resuscitation may have a normal INR upon arrival to the ICU, but this may only be a transient finding.

In addition to the coagulopathy associated with major trauma, fibrinolysis is especially deleterious in severely injured trauma patients and carries an associated mortality well upwards of 50\% [24,56,57]. Many patients with primary fibrinolysis from severe hemorrhagic shock may never survive to reach the ICU. The recently concluded CRASH-2 trial is the only class I evidence to date showing a 30 day survival benefit for a resuscitative therapy [58]. Subgroup analysis showed that the benefit was greatest when therapy was instituted within 1 hour of admission. However, subgroup analysis showed that mortality actually increased when therapy was instituted after 3 hours, suggesting that the risks of therapy outweighed the benefits in patients who survived beyond that timeframe [59]. It may therefore be prudent to carefully consider whether to administer anti-fibrinolytic therapy in the ICU, even if the patient has laboratory evidence of fibrinolysis.

Finally, trauma patients frequently convert from a hypocoagulable to a hypercoagulable profile once they survive the initial insult and hemorrhage [60]. This is important to monitor in the ICU, as long term morbidity and mortality from thromboembolic events has a significant impact; and it is important to discontinue hemostatic support once the patient is no longer coagulopathic. 


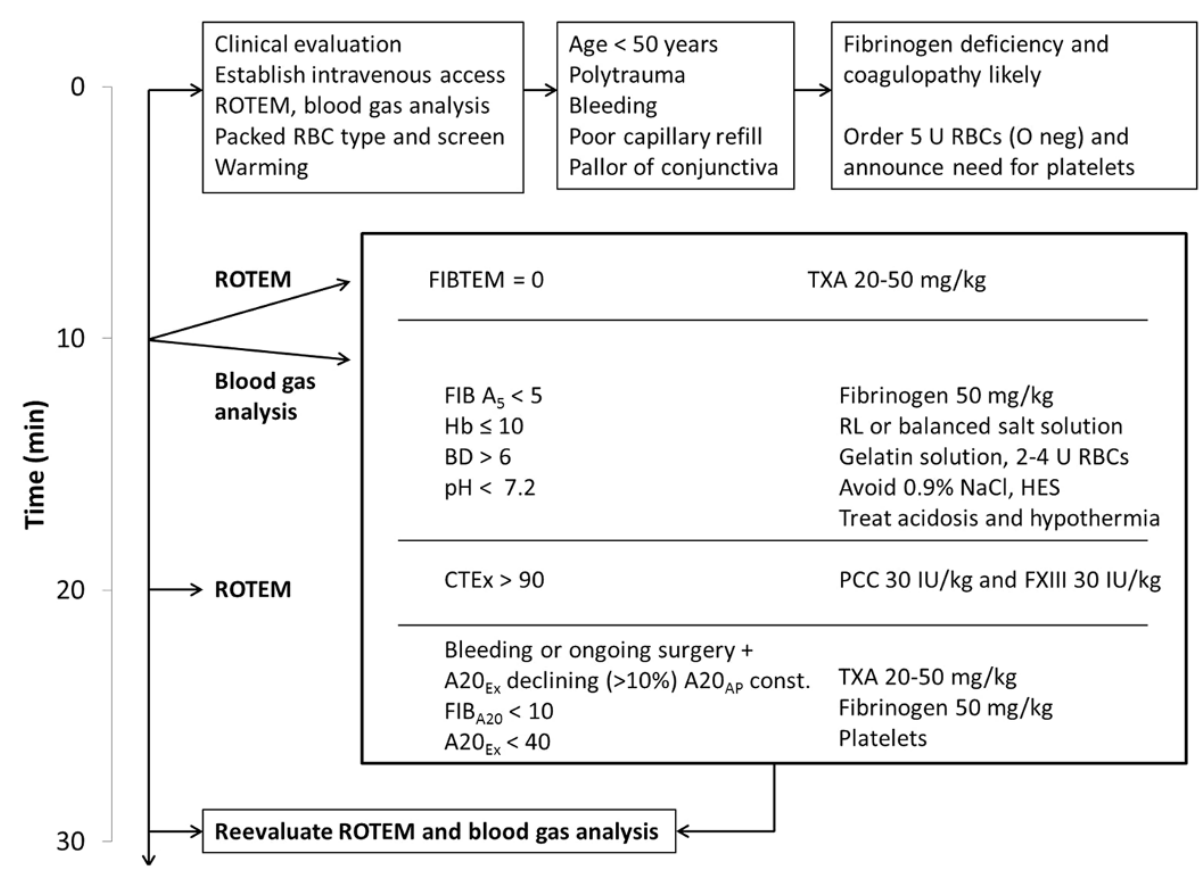

Figure 3 One possible decision tree algorithm for the management of clinical bleeding using ROTEM ${ }^{\circledR}$-guided goal-directed resuscitation with targeted hemostatic factors [adopted from [27].

\section{Fluid support in the ICU}

Until definitive hemostasis has been achieved in the ICU, use of non-hemostatic/non-oxygenating fluids should generally be minimized, unless concentrates are used. Resuscitation fluids should consist mainly of blood products and hemostatic agents. Over-aggressive fluid administration in the bleeding patient can lead to clot disruption and exacerbate hemorrhage, resulting in the vicious cycle of increased blood loss and fluid administration known as "fluid creep" (Figure 4). Moderate hypotension during the period of "early resuscitation" is generally acceptable in our experience, with possible adjustment for patients with pre-existing cardiac dysfunction or co-existing CNS injury [8,29]. Transfusion should aim for a hemoglobin between 8 and $10 \mathrm{~g} / \mathrm{dL}$ while the patient is actively bleeding, to provide a margin for error and also to support hemostasis [61].

Once definitive hemostasis has been achieved, the patient may still be significantly hypo-perfused. Prolonged activation of the noradrenergic axis results in profound vasoconstriction, which may be aggravated by hypothermia. Hypoperfusion impairs cellular energetics and results in loss of endothelial integrity. Inflammatory cytokines and ischemia-reperfusion injury may result in cellular edema reducing the lumen of capillaries and producing the "no-reflow" phenomenon [8]. Full resuscitation of the severely injured patient requires not only arrest of bleeding and restoring hemodynamic stability but also re-establishing micro-circulatory flow, restoring end-organ homeostasis, and repaying the "oxygen debt". Failure to do this may result in the development of subsequent organ dysfunction in the hemodynamically stable but still under-resuscitated patient [62]. Therefore, assuring adequate completeness of resuscitation is the next critical challenge for the ICU physician after establishing hemostasis. Unfortunately, over-resuscitation as well as under-resuscitation may have adverse consequences, and the "optimal" endpoint of resuscitation may not be at all obvious.

Fluid selection may have implications for microcirculatory perfusion, which should be the primary goal of resuscitation once hemostasis has been attained. Some data suggest that fluids exert micro-circulatory effects independent of volume expansion or oxygencarrying capacity [63-65]. There is some evidence that hyperviscous solutions such as hydroxyethyl starch $130 / 0.4$ or hypertonic solutions such as $7 \%$ saline with dextran may have a greater benefit in re-establishing microvascular perfusion than standard crystalloids [65-68], and that the micro-circulatory benefit may be limited to a relatively small initial bolus [65]. "Small volume resuscitation" has been studied more in the pre-hospital and early stages of resuscitation as an adjunct to hypotensive resuscitation $[8,14,29,69]$, further study is required to understand the effects of different resuscitation fluids on microvascular perfusion separate from 
their effects as volume expanders and their potential role in the ICU resuscitation phase. A detailed review of fluid selection for the post-resuscitation trauma patient is beyond the scope of this review and available elsewhere [70].

\section{Need for further interventions}

In some cases it may be extremely difficult to differentiate surgical from coagulopathy-associated bleeding. Continuing transfusion requirement and evidence of ongoing blood loss in the setting of aggressive corrective efforts usually imply ongoing surgical bleeding, irreversible shock, or profound hepatic dysfunction. Because blood products generally increase the risk of infection, organ failure, and mortality, and because of the cumulative effect of ongoing shock, it may be prudent to set a limit on ongoing transfusion requirements before mandating surgical or angiographic re-evaluation of the patient to rule out occult injury. The ICU physician should discuss this issue at an early juncture with the surgical team. Wounds with particularly difficult anatomy and a propensity for missed injuries should prompt even greater vigilance.

\section{Monitoring, assessment, and endpoints of resuscitation in the ICU \\ Endpoints of resuscitation}

While the patient is actively bleeding - whether from surgical or medical causes - resuscitation is aimed at minimally acceptable levels of organ perfusion and homeostasis, with the goal of avoiding irreversible shock while not exacerbating hemorrhage. It is not possible to focus on definitive "endpoints" when the target is still moving. Physiologic assessment and resuscitative efforts are focused during this stage on hemostasis and on attaining basic goals with respect to temperature, acidosis, urine output and hemodynamics [8].

Once hemostasis has been attained, resuscitation should aim at the complete restoration of macro- and

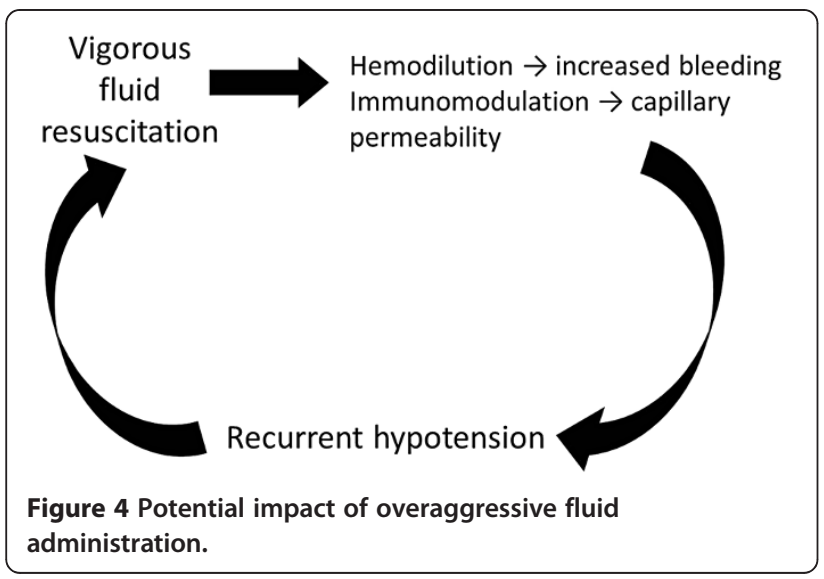

micro-circulatory stability and of end-organ homeostasis in the ICU. Although not directly supported by randomized trials, this may be achieved with additional fluid administration to restore circulating blood volume, in combination with analgesic and sedative agents to dilate constricted blood vessels and improve microvascular perfusion. Basic hemodynamic goals include a stable systolic pressure $>100 \mathrm{~mm} \mathrm{Hg}$ and a heart rate less than $100 \mathrm{bpm}$. Urine output should be normal. Normalization of $\mathrm{pH}$, lactate and base deficit are all suggestive of restored micro-circulatory perfusion [8,29]. Aggressive correction of any residual hypothermia and coagulopathy should also be priorities during this phase. These goals may need to be modified based on patient comorbidities and/or the presence of concomitant CNS injury.

How much fluid loading is beneficial is a matter of debate. Numerous studies have shown that underresuscitation results in "occult" or "cryptic" shock, a state of compensated shock, which predisposes to organ dysfunction in the ICU $[62,71]$. Some series have found that $85 \%$ of severely injured patients with normal hemodynamics may be hypoperfused [72,73]. Studies have consistently indicated that persistent elevations of serum base deficit or lactate levels are suggestive of occult hypoperfusion and are predictive or poor outcome in critically ill patients $[16,62,74-76]$. Some authors have proposed that lactate is a better marker of occult hypoperfusion than base deficit in this population [77]. A recent study found that using serial serum lactate levels to guide treatment of critically ill patients reduced overall in-hospital mortality [78].

The above data, combined with observations that survivors of critical injury tended to exhibit hyperdynamic (or "supranormal") cardiac output [79] and that young severely injured trauma patients frequently manifested significant occult myocardial dysfunction [72]. led to the practice of aggressive volume loading augmented by the use of inotropes to achieve pre-specified goals for oxygen delivery and cardiac function in the ICU [80-86]. These goals were often difficult to achieve, required substantial volume loading and pharmacologic support, and had mixed results [86-90] with a high rate of intraabdominal hypertension, pulmonary dysfunction, and other complications $[69,91]$. Although there seems to be some evidence that patients who are able to mount a hyperdynamic response to injury may have better outcomes [92], current evidence suggests that supportive care with fluids to "normal" resuscitation endpoints produces equivalent results to goal-directed resuscitation to preset "supranormal" $\mathrm{DO}_{2}$ values, and avoids the adverse consequences of over-resuscitation [90]. Taken together, it appears that the physiologic cost of supranormal resuscitation is high, and the results at the micro- 
circulatory level are too questionable to support routine use of this approach.

The particular endpoint chosen may also play a role [92-95]. Mixed venous oxygen saturation [84]. central venous oxygen saturation [96] and left ventricular function [97-99] have all been studied as possible endpoints, as have indicators of regional perfusion. In all likelihood, the majority of the time these are functionally equivalent: responders tend to do well by all endpoints, and non-responders tend to do poorly [14]. It is unclear how useful these are as specific targets for resuscitation, as opposed to simply being markers of physiologic response.

Supranormal and goal-directed approaches to resuscitation presume that attaining macro-circulatory targets such as cardiac output and oxygen delivery will directly lead to perfusion at the level of the microcirculation (Figure 5) [100]. It is far from clear that this is actually the case. Evolving evidence suggests that beyond a minimal level of cardiac output and arterial pressure, there may be considerable disassociation between the micro- and macro-circulation $[101,102]$. Several studies have shown not only a lack of coupling between hemodynamics and the microcirculation, but also considerable individual variation in the microvascular response to interventions targeting upstream endpoints [103-105].

In summary, the patient in whom hemostasis is achieved early, limiting the dose of shock and the extent of underlying organ dysfunction, may respond well to aggressive fluid loading to restore tissue perfusion; whereas the patient with prolonged hemorrhage and shock resulting in significant organ dysfunction may not. While a specific, targeted endpoint for resuscitation is important for guiding subsequent therapy, the actual endpoint selected may not be important as the use of goal-directed approach. Other considerations may influence the ICU physician's approach in specific cases. Regardless, it is evident that there is considerable inter- and intra-patient variation in the Frank-Starling curves of fluid responsiveness [69], and therapy must be carefully tailored to individual needs and responses.

\section{Missed injuries and determinants of futility}

Not all patients respond to aggressive resuscitative measures. This can be due to occult injury or poor physiologic response. A recent review of undiagnosed injuries and outcomes, suggested up to $6.5 \%$ of all trauma-related deaths were attributable to clinically undiagnosed injury [106]. Inability to explain the patient's declining physiologic status should generally prompt an aggressive search for missed injuries, which may entail radiographic, angiographic and sonographic evaluation, and in some cases operative re-exploration.
After having ruled out occult injury and possible sources of ongoing hemorrhage, further lack of response to continued resuscitation may suggest exhaustion of physiologic reserves consistent with irreversible shock. Acidosis and hypothermia refractory to aggressive supportive measures, decreasing responsiveness to fluids or to vasopressors ("vasoplegia"), evidence of persistent hyperfibrinolysis on viscoelastic monitoring and diminished tissue oxygen saturation levels have all been suggested to correlate with likelihood of irreversible shock and non-survivable injury. While early prediction of mortality and organ dysfunction is possible, irreversible shock can generally only be identified after repeated and persistent efforts to resuscitate have proven unsuccessful. Futility may become an issue for these patients. The nature and severity of the injuries and the amount of resources already expended should certainly factor into the equation of when to discontinue further resuscitative efforts.

\section{Post-resuscitation complications in the trauma patient}

As previously discussed, aggressive resuscitation of the polytrauma patient is not without the potential for significant complications. This section will focus systematically on commonly encountered clinical problems in the ICU that arise as a consequence of severe hemorrhagic shock and resuscitation, including complications of transfusion and fluid therapy.

\section{Hypothermia}

The development of hypothermia in trauma patients is complex and related to multiple factors including presence of shock, vasodilation from anesthetic agents, environmental exposure, infusion of large volumes of fluids, and surgical exposure [107,108]. Polytrauma patients presenting with uncontrolled, nontherapeutic hypothermia $\left(<35^{\circ} \mathrm{C}\right)$ appear to have an associated increase in mortality $[107,109-112]$ although this is an inconsistent finding in published studies [113]. Whether applied therapeutically or associated with severely injured trauma patients, hypothermia has multifactorial effects on the coagulation system with moderate hypothermia $\left(32^{\circ} \mathrm{C}-34^{\circ} \mathrm{C}\right)$ reducing coagulation activity by $10 \%$ for every decrease in temperature by one degree Celsius as well as reducing the number and function of platelets $[35,44,114]$. In the setting of mild to moderate, controlled hypothermia $\left(>33^{\circ} \mathrm{C}\right)$, this degree of coagulopathy does not independently contribute to clinically significant bleeding [115]. During active hemorrhage and resuscitation, however, avoidance of severe hypothermia through active warming measures can be recommended based on the association of hypothermia with increased mortality as stated above. 


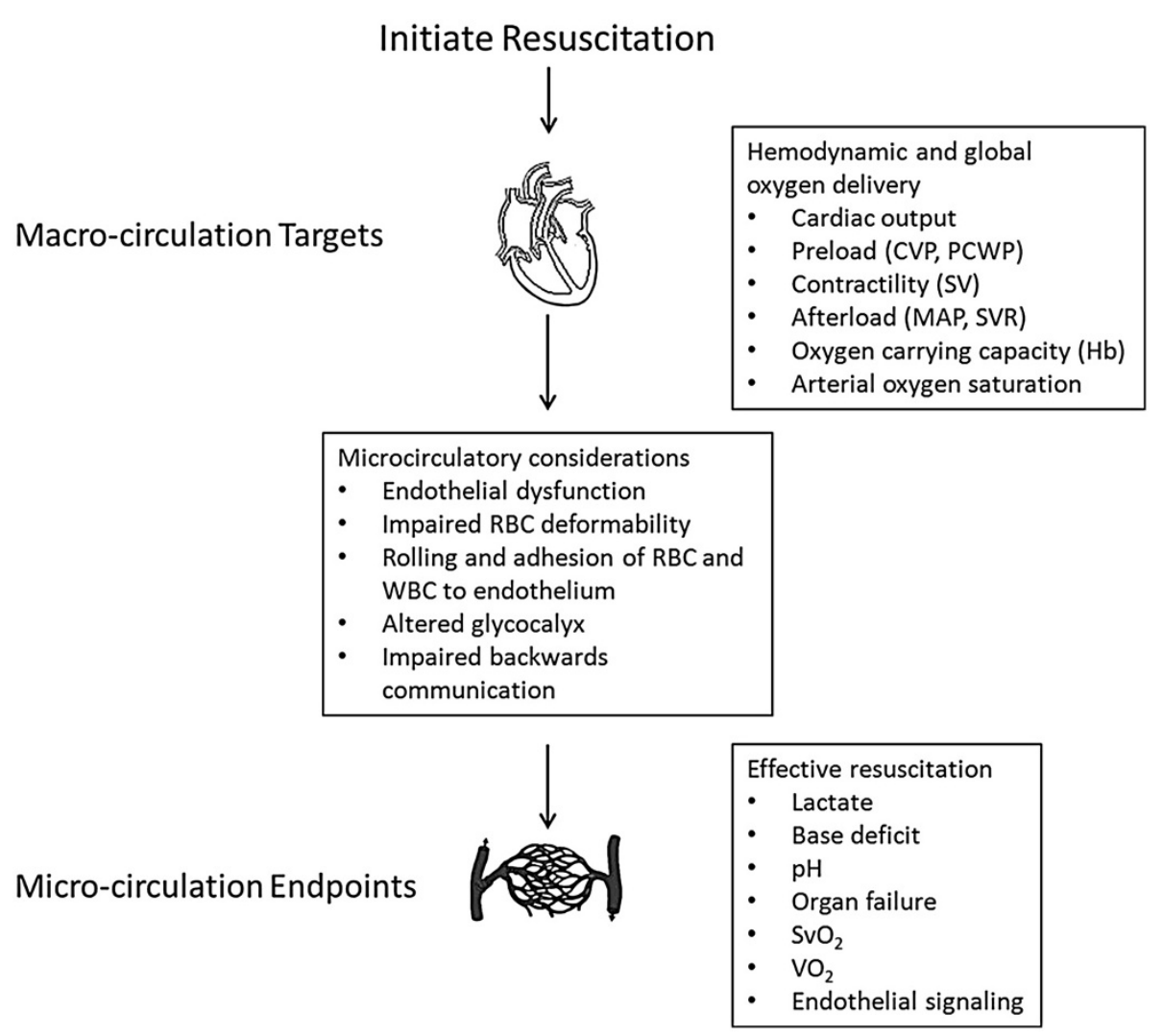

Figure 5 Macro- and micro-circulatory endpoints for resuscitation [adopted from $[95,100]$.

In addition to alterations in coagulation, hypothermia has been associated with dysrhythmias and infections. Dysrhythmias may occur with moderate to severe hypothermia including bradycardia, first degree heart block and QT prolongation [116]. Although there are no consistent findings reported in the hypothermic trauma patient, continuous cardiac monitoring and evaluation of metabolic parameters is warranted. Infection risk for surgical site infections and pneumonia has been shown to be associated with hypothermia [117-119]. Although data to support a strong cause and effect relationship for hypothermia and increased morbidity and mortality, does not exist, our institution targets normothermia throughout the resuscitation and early ICU phase of care. Thus, active rewarming efforts initiated in the resuscitation bay or operating room are aggressively continued in the ICU. Targeted temperature management systems, preferably as part of an institutional protocol, can be used to achieve normothermia. Combination of different techniques including surface, intravascular, fluid, and forced-air warming systems provide a multimodal approach to achieving and maintaining normothermia. A recent review of the relationship of hypothermia with acidosis and coagulopathy can be accessed for more detail [120].

\section{Cardiopulmonary complications}

TRALI Transfusion-related acute lung injury (TRALI) is underreported and under-recognized, yet remains the leading cause of transfusion-related mortality [121,122]. TRALI is defined as an acute lung injury (ALI) that occurs during or within 6 hours of a transfusion, with no temporal relationship to alternative risk factors, and no evidence of circulatory overload [122-125]. As an ALI by definition, TRALI is associated with acute onset hypoxemia $\left(\mathrm{PaO} 2 / \mathrm{FiO}_{2}\right.$ gradient $\left.\leq 300\right)$ and bilateral infiltrates on the chest radiograph [122,124]. "Possible TRALI" is the diagnostic nomenclature used when alternative explanations for ALI exist, such as aspiration pneumonitis, near drowning, lung contusion, or other traumarelated etiologies. TRALI is thought to be the result of two critical events: activation of the pulmonary vascular endothelium with priming of neutrophils, followed by transfusion of antibodies to leukocyte antigens with resultant activation and neutrophil-mediated cytotoxicity [126]. TRALI may occur as often as once for every 1271 units transfuse [127] with an incidence up to $8 \%$ in ICU patients [128]. Watson and colleagues estimated a cumulative increase in the risk of ALI from each unit of FFP at $2.5 \%$, and of multiple organ failure from each unit at $2.1 \%$ [129]. 
Treatment for TRALI is supportive, and a lung-protective, low tidal volume strategy is recommended to prevent additional lung injury [130]. Subsequent transfusions should be limited when possible since repeated transfusions worsen outcomes in existing ALI [130,131]. If a restrictive transfusion strategy is not practicable, then avoidance of plasma from donors with pathogenic antibodies, administration of washed blood components, and use of products with the shortest length of storage possible are recommended [123]. In one study of 284 trauma patients, patients transfused with ABOcompatible plasma had over a $10 \%$ higher rate of acute respiratory distress syndrome [132]. Hence ABO identical blood products, as opposed to ABO-compatible products, should be used whenever possible.

TACO Although the reported incidence varies widely, transfusion-associated circulatory overload (TACO) is currently the second most common cause of transfusionrelated mortality $[133,134]$. TACO may be confused with TRALI since both conditions present with similar clinical and radiological findings. Large volume transfusions are not required for the development of TACO, which may particularly affect infants and the elderly. The key pathophysiologic difference between the two syndromes is lack of an antibody-mediated phenomenon with TACO [135]. Brain natriuretic peptide may be a helpful laboratory test for differentiating TACO from TRALI; levels are typically increased more than fourfold in the former [122]. Treatment consists of supportive care, diuretic therapy, and administration of any future transfusions at a reduced infusion rate.

Distinguishing TACO and TRALI from acute respiratory distress syndrome can be challenging since these disorders share several clinical characteristics, including the presence of bilateral, diffuse, infiltrates on the chest radiograph, and acute onset of respiratory distress and hypoxemia. Table 1 summarizes key criteria that may be used to differentiate these challenging disorders.

\section{Renal and electrolyte complications}

Rhabdomyolysis Rhabdomyolysis is defined by the serum elevation of creatinine kinase $(\mathrm{CK})$ as the result of destruction or disintegration of striated muscle [136]. Muscular trauma is the most common etiology, but the in some cases the cause can remain elusive. Heat stroke, inherited disorders of carbohydrate metabolism, electrical injuries, neuroleptic malignant syndrome, and medications can also cause rhabdomyolysis. Approximately $10-50 \%$ of patients with rhabdomyolysis develop acute renal failure $[137,138]$. CK and myoglobin levels are the most commonly used laboratory tests used to diagnose and monitor rhabdomyolysis. Normal CK levels are less than $260 \mathrm{U} / \mathrm{L}$, and levels greater than $5000 \mathrm{U} / \mathrm{L}$ are associated with renal failure. With appropriate treatment, CK levels rise within 12 hours of injury, peak by 3 days, and fall 3-5 days afterwards [136]. Myoglobin has a half-life of less than 3 hours and may be a more sensitive laboratory indicator. Normal myoglobin levels are less than $1.5 \mathrm{mg} / \mathrm{dL}$. Treatment of rhabdomyolysis consists of early and aggressive fluid therapy, with a target of 100 to $200 \mathrm{~mL}$ of urine per hour. Mannitol, bicarbonate, and various antioxidants are often used, but there are limited data to support the efficacy of these agents, and in these agents are generally avoided in the authors' institution [136]. At least one study showed a benefit of forced diuresis with furosemide in casualties suffering from crush injuries [138]. Renal replacement therapy may be required, especially for patients with severe acidosis and hyperkalemia. It should be noted that during the renal recovery phase in rhabdomyolysis, hypercalcemia is a common electrolyte derangement; supplemental calcium should be avoided during this period unless hypocalcemia is symptomatic.

Hyperkalemia and hypocalcemia While a comprehensive review of fluid and electrolyte management in the ICU is beyond the scope of this paper, a few electrolyte derangements unique to resuscitation from hemorrhage and severe shock are worth noting. Hyperkalemia can occur as the result of stored red blood cell membrane degradation, loss of cellular potassium pumps, and decreased adenosine triphosphate synthesis [139]. In one reported series, 16 patients who received red blood cell transfusions developed serum potassium levels between 5.9-9.2 $\mathrm{mEq} / \mathrm{L}$ and sustained cardiac arrest [140]. Hyperkalemia should be treated promptly with insulin, glucose and calcium to protect the myocardium and increase intracellular potassium shifts. Emergent renal replacement therapy is indicated for life-threatening hyperkalemia, with or without concomitant renal failure. Hypocalcemia, owing to the binding of calcium to citrate preservatives in blood products, is another commonly encountered electrolyte derangement that may persist after admission to the ICU following damage control resuscitation. Hypocalcemia may impair hemostasis and contribute to hypotension, and should be promptly corrected if symptomatic.

\section{Intra-abdominal hypertension and abdominal compartment syndrome}

With the advances in DCS and DCR, an improved understanding of intra-abdominal hypertension (IAH) and abdominal compartment syndrome (ACS) has evolved [141]. IAH is defined as sustained or repeated pathologic elevation of intra-abdominal pressure $\geq 12$ $\mathrm{mmHg}$ and ACS is defined as the sustained elevation of 
Table 1 Distinguishing TRALI from TACO and ARDS

\begin{tabular}{llll}
\hline Finding & TRALI & ARDS & TACO \\
\hline Vital signs & $\begin{array}{l}\text { May be febrile; hypotension } \\
\text { more common than } \\
\text { hypertension }\end{array}$ & Variable & $\begin{array}{l}\text { Typically normothermic; } \\
\text { hypertension }\end{array}$ \\
\hline Clinical examination & Crackles & Crackles & $\begin{array}{l}\text { Crackles, S3, jugular } \\
\text { venous distension }\end{array}$ \\
\hline ECHO findings & $\begin{array}{l}\text { Normal to slightly decreased } \\
\text { ventricular function; } \\
\text { no evidence of left } \\
\text { atrial hypertension }\end{array}$ & $\begin{array}{l}\text { Normal to slightly decreased } \\
\text { ventricular function; no } \\
\text { evidence of left atrial } \\
\text { hypertension }\end{array}$ & Decreased ejection fraction \\
\hline $\begin{array}{l}\text { Pulmonary artery } \\
\text { occlusion pressure }\end{array}$ & $<18$ mmHg & $<18$ mmHg & $>18 m m H g$ \\
\hline Fluid balance & $\begin{array}{l}\text { Hyper-, hypo-, } \\
\text { or normovolemic }\end{array}$ & $\begin{array}{l}\text { Hyper-, hypo-, } \\
\text { or normovolemic }\end{array}$ & Hypervolemic \\
\hline $\begin{array}{l}\text { Brain natriuretic } \\
\text { peptide (BNP) level }\end{array}$ & $<200$ pg/mL & $<200$ pg/mL & $>1200$ pg/mL \\
\hline White blood cell count & $\begin{array}{l}\text { Typically decreased; } \\
\text { may be transient }\end{array}$ & Variable & Usually unchanged from baseline \\
\hline Leukocyte antibodies & $\begin{array}{l}\text { Donor leukocyte } \\
\text { antibodies present; crossmatch } \\
\text { incompatibility between } \\
\text { donor and recipient }\end{array}$ & $\begin{array}{l}\text { Donor leukocyte antibodies } \\
\text { may or may not be present }\end{array}$ & Donor leukocyte antibodies \\
& $\leq 300$ & may or may not be present
\end{tabular}

intra-abdominal pressures $\geq 20 \mathrm{mmHg}$ that are associated with new organ dysfunction [142,143]. Risk factors for ACS include more than $3 \mathrm{~L}$ of crystalloid infusion or more than 3 units of PRBCs in the emergency department, hypothermia below $34^{\circ} \mathrm{C}$, acidosis (base deficit $<-14 \mathrm{mmol} / \mathrm{L}$ ), and anemia (hemoglobin $<8 \mathrm{~g} / \mathrm{dL}$ [144]. Additional factors include circulatory shock conditions and the amount of crystalloid fluids administered. Aggressive fluid resuscitation to targeted "supranormal" endpoints has been shown to result in an increased incidence of AC [91].

IAH and ACS have profound effects on multiple organ systems. Elevation of the intra-abdominal pressure to levels of 10 to $15 \mathrm{mmHg}$ can cause cardiac failure as the result of inferior vena cava compression and compromised venous return [145]. Direct compression of the heart and pulmonary vessels results in elevated intrathoracic pressures and a rightward shift and flattening of the Starling curve [145]. At intra-abdominal pressures as low as $10 \mathrm{~mm} \mathrm{Hg}$, oliguria may manifest as the result of compression of intrarenal blood vessels [143]. The lowpressure postglomerular intrarenal vascular network is highly sensitive to compressive forces; and renal artery blood flow has been shown in animal models to decrease in a linear fashion with increases in intra-abdominal pressure [146]. IAH and ACS can cause an imbalance between vasodilatory and vasoconstrictive mediators, mimicking the pathophysiology of hepatorenal syndrome, and causing hepatic insufficiency. Transmission of abdominal pressure to other compartments may result in the "multiple compartment syndrome" [147].
Successful management of IAH and ACS begins with prompt diagnosis. Physical examination has proven unreliable with a sensitivity of less than $60 \%$, and the current standard of care is to measure intra-abdominal pressure by transducing urinary bladder pressure via an indwelling catheter $[143,148]$. Bladder pressures should be measured in the supine position at end-expiration, with the transducer zeroed at the iliac crest in the midaxillary line [142,143]. Once diagnosed, there are few nonsurgical management options. Sedation, analgesia, and neuromuscular blockade, when combined with diuresis, fluid restriction, dialysis, or other interventions to attenuate hypervolemia, may avert the need to proceed to laparostomy. In many cases, prompt opening of the abdomen is the only effective intervention for restoring end-organ function [145,149]. Laparostomy practices have become more prevalent with the practice of DCS, with reported mortality improvements for severe abdominal trauma approaching 50\% [3].

\section{Hyperglycemia}

Whereas hyperglycemia in ICU patients has remained a topic of debate over the past two decades, glucose elevations are very common in critically injured trauma patients, and tight glucose control has been associated with improved outcomes in this population [150]. In a retrospective cohort of 2,028 adult trauma patients, maintenance of blood glucose between $80-110 \mathrm{mg} / \mathrm{Dl}$ (4.4-5.6 $\mathrm{mmol} / \mathrm{L})$ utilizing an intensive insulin infusion protocol was associated with a decrease in hospital length of stay and mortality [151]. In another case 
control study, improved mortality was demonstrated in a trauma population when the blood glucose was maintained less than $150 \mathrm{mg} / \mathrm{dL}$ [152].

\section{Adrenal insufficiency}

Adrenal insufficiency has a high incidence amongst critically injured patients [153]. In one prospective observational study, up to $12 \%$ of all patients in shock had simultaneous hypothyroidism and adrenal insufficiency [154]. Trauma-related adrenal insufficiency has been correlated with systemic inflammatory response syndrome, and the multicenter HYPOLYTE study found that a continuous infusion of hydrocortisone $(200 \mathrm{mg} / \mathrm{d}$ for 5 days, followed by a taper) resulted in a statistically significantly lower rate of hospital-acquired pneumonia (hazard ratio $0.51 ; 95 \%$ CI $0.30-0.83 ; \mathrm{p}=0.007$ ) and hyponatremia [155]. The hydrocortisone group had more days of mechanical ventilation, but no differences regarding other infections, organ failure, or mortality were observed. The results of this study contrast with the CRASH study, which showed an increased risk of death in TBI patients treated with high-dose methylprednisolone [156]. Before the use of steroids can be widely recommended, the findings from HYPOLYTE should be confirmed with additional studies involving traumatically injured ICU patients, including TBI patients.

\section{TRIM}

Allogeneic blood transfusions introduce foreign antigens into the recipient, and can cause a constellation of beneficial or deleterious clinical effects that are collectively known as transfusion-related immunomodulation (TRIM) [123]. Though TRIM has been thought to have beneficial effects for renal allograft patients as evidenced by improved graft survival, deleterious effects in the trauma population include increased risk of infections and potentially higher mortality. The deleterious effects of TRIM on trauma patients are purportedly caused by soluble, white blood cell derived mediators accumulating in the supernatant fluid of stored red blood cells and soluble HLA peptides circulating in allogeneic plasma [123]. A host of proinflammatory effects are postulated in TRIM, leading to an increased incidence of postoperative bacterial infections, activation of endogenous cytomegalovirus or human immunodeficiency infection, and increased short-term mortality. TRIM appears to be a biological phenomenon that may be attenuated by the use of white blood cell (WBC) reduced blood products, although based on limited data from randomized controlled trials, universal WBC reduction is still not widely practiced.

Although CPDA red cell preservation techniques allow storage for up to 42 days, there is evidence that storage beyond 14 days significantly increases inflammatory mediators and by-products which may contribute to immune dysfunction [157,158]. Long-term storage also leads to red cell deformity which can cause trapping in the microcirculation and ischemia. Red cell hemolysis may lead to the accumulation of free radicals and to regional and systemic vasoconstriction, as well as oxidative injury [159]. These effects could potentially be synergistic with red blood cell damage and decreased microcirculatory flow directly produced by hemorrhagic shock [160]. Duration of transfused red cell storage has been independently associated with an increased mortality and risk of multiple organ failure in trauma patients even with leukoreduction [159-163]. Although the data are mostly based on observational studies [159], trauma patients are the largest surgical consumers of blood products, and often receive the oldest blood. During acute resuscitation of massive hemorrhage it may not be feasible to choose only more recently stored units, but as transfusion requirements decrease the ICU physician may wish to be more selective.

\section{Summary}

Polytrauma patients with severe shock from hemorrhage and massive tissue injury present major challenges for management and resuscitation in the intensive care setting. ICU physicians must be prepared to receive patients in varying degrees of stability and be ready to take over and complete the resuscitative process. In some cases "fine tuning" may be all that is required before addressing long-term critical care needs; in others, the intensivist must be prepared to undertake immediate massive resuscitation and correction of severe physiologic derangements if the patient is to survive the first 24 hours of admission. How well the ICU physician is prepared to meet these challenges may critically affect 24 hour survival after severe injury, and also the development of potentially life-threatening complications. As the patient becomes more fully stable, the ICU physician can then transition priorities towards longer-range management issues.

The past decade has seen radical changes in our approaches to resuscitation from hemorrhage and polytrauma. These changes have drastically influenced how resuscitation is carried out both in the resuscitation bay and operating room with carryover to the ICU. Future developments will improve our understanding of the micro-circulation and the interaction between hemostasis, inflammation and the endothelium and will influence how we manage these complex and challenging patients.

\section{Abbreviations}

ACS: Abdominal compartment syndrome; ALI: Acute lung injury; CK: Creatinine kinase; CNS: Central nervous system; DCR: Damage control resuscitation; DCS: Damage control surgery; FFP: Fresh frozen plasma; 
IAH: Intra-abdominal hypertension; ICU: Intensive care unit; INR: International normalized ratio; PT: prothrombin time; PTT: Partial thromboplastin time; rFVIIla: Activated factor VIla; TACO: Transfusion-associated circulatory overload; TBI: Traumatic brain injury; TRALI: Transfusion-related acute lung injury; TRIM: Transfusion-related immunomodulation.

\section{Competing interests}

The authors declare that they have no competing interests.

\section{Authors' contributions}

All authors contributed to review concept, design and acquisition, analysis and interpretation of the literature. Finally all authors read and approved the submitted manuscript.

Received: 27 February 2012 Accepted: 28 August 2012

Published: 18 September 2012

\section{References}

1. Rotondo MF, Schwab CW, McGonigal MD, Phillips GR 3rd, Fruchterman TM Kauder DR, Latenser BA, Angood PA: 'Damage control': an approach for improved survival in exsanguinating penetrating abdominal injury. J Trauma 1993, 35:375-382. discussion 382-3.

2. Scalea TM, Boswell SA, Scott JD, Mitchell KA, Kramer ME, Pollak AN: External fixation as a bridge to intramedullary nailing for patients with multiple injuries and with femur fractures: damage control orthopedics. J Trauma 2000, 48:613-621. discussion 621-3.

3. Shapiro MB, Jenkins DH, Schwab CW, Rotondo MF: Damage control: collective review. J Trauma 2000, 49:969-978.

4. Rotondo MF, Bard MR: Damage control surgery for thoracic injuries. Injury 2004, 35:649-654.

5. Hess JR: Blood and coagulation support in trauma care. Hematology Am Soc Hematol Educ Program 2007, 1:187-191.

6. Scalea T: What's new in trauma in the past 10 years. Int Anesthesiol Clin 2002, 40:1-17.

7. Butcher N, Balogh ZJ: AIS > 2 in at least two body regions: a potential new anatomical definition of polytrauma. Injury 2012, 43:196-199.

8. Dutton RP: Current concepts in hemorrhagic shock. Anesthesiol Clin 2007, 25:23-34. viii.

9. Barbee RW, Reynolds PS, Ward KR: Assessing shock resuscitation strategies by oxygen debt repayment. Shock 2010, 33:113-122.

10. Sperry JL, Minei JP, Frankel HL, West MA, Harbrecht BG, Moore EE, Maier RV, Nirula R: Early use of vasopressors after injury: caution before constriction. J Trauma 2008, 64:9-14.

11. Cohn SM: Potential benefit of vasopressin in resuscitation of hemorrhagic shock. J Trauma 2007, 62:S56-S57.

12. Voelckel WG, Convertino VA, Lurie KG, Karlbauer A, Schochl H, Lindner KH, Trimmel H: Vasopressin for hemorrhagic shock management: revisiting the potential value in civilian and combat casualty care. J Trauma 2010, 69(Suppl 1):S69-S74.

13. Cohn SM, McCarthy J, Stewart RM, Jonas RB, Dent DL, Michalek JE: Impact of low-dose vasopressin on trauma outcome: prospective randomized study. World J Surg 2011, 35:430-439.

14. Fouche Y, Sikorski R, Dutton RP: Changing paradigms in surgical resuscitation. Crit Care Med 2010, 38:S411-S420.

15. Chesnut RM, Marshall LF, Klauber MR, Blunt BA, Baldwin N, Eisenberg HM, Jane JA, Marmarou A, Foulkes MA: The role of secondary brain injury in determining outcome from severe head injury. J Trauma 1993, 34:216-222.

16. Davis JW, Shackford SR, Mackersie RC, Hoyt DB: Base deficit as a guide to volume resuscitation. J Trauma 1988, 28:1464-1467.

17. Davis JW, Parks SN, Kaups KL, Gladen HE, O'Donnell-Nicol S: Admission base deficit predicts transfusion requirements and risk of complications. J Trauma 1996, 41:769-774

18. Haddad SH, Arabi YM: Critical care management of severe traumatic brain injury in adults. Scand J Trauma Resusc Emerg Med 2012, 20:12.

19. Cosgriff N, Moore EE, Sauaia A, Kenny-Moynihan M, Burch JM, Galloway B: Predicting life-threatening coagulopathy in the massively transfused trauma patient: hypothermia and acidoses revisited. J Trauma 1997, 42:857-861. discussion 861-2.
20. Moore FA, Moore EE, Sauaia A: Blood transfusion. An independent risk factor for postinjury multiple organ failure. Arch Surg 1997, 132:620-624. discussion 624-5.

21. Sauaia A, Moore FA, Moore EE, Norris JM, Lezotte DC, Hamman RF: Multiple organ failure can be predicted as early as 12 hours after injury. I Trauma 1998, 45:291-301.

22. Moore FA, McKinley BA, Moore EE: The next generation in shock resuscitation. Lancet 2004, 363:1988-1996.

23. Johansson PI, Stensballe J, Vindelov N, Perner A, Espersen K: Hypocoagulability, as evaluated by thrombelastography, at admission to the ICU is associated with increased 30-day mortality. Blood Coagul Fibrinolysis 2010, 21:168-174.

24. Kashuk JL, Moore EE, Sawyer M, Le T, Johnson J, Biffl WL, Cothren CC, Barnett C, Stahel P, Sillman CC, Sauaia A, Banerjee A: Postinjury coagulopathy management: goal directed resuscitation via POC thrombelastography. Ann Surg 2010, 251:604-614

25. Johansson PI, Ostrowski SR: Acute coagulopathy of trauma: balancing progressive catecholamine induced endothelial activation and damage by fluid phase anticoagulation. Med Hypotheses 2010, 75:564-567.

26. Kozek-Langenecker S: Management of massive operative blood loss. Minerva Anestesiol 2007, 73:401-415.

27. Fries $D$, Innerhofer $P$, Schobersberger $W$ : Time for changing coagulation management in trauma-related massive bleeding. Curr Opin Anaesthesio 2009, 22:267-274.

28. Segal JB, Dzik WH: Transfusion Medicine/Hemostasis Clinical Trials Network: Paucity of studies to support that abnormal coagulation test results predict bleeding in the setting of invasive procedures: an evidence-based review. Transfusion 2005, 45:1413-1425.

29. Stahel PF, Smith WR, Moore EE: Current trends in resuscitation strategy for the multiply injured patient. Injury 2009, 40(Suppl 4):S27-S35.

30. Jansen JO, Scarpelini S, Pinto R, Tien HC, Callum J, Rizoli SB: Hypoperfusion in severely injured trauma patients is associated with reduced coagulation factor activity. J Trauma 2011, 71:S435-S440.

31. MacLeod JB, Lynn M, McKenney MG, Cohn SM, Murtha M: Early coagulopathy predicts mortality in trauma. J Trauma 2003, 55:39-44

32. Johansson PI, Stissing T, Bochsen L, Ostrowski SR: Thrombelastography and tromboelastometry in assessing coagulopathy in trauma. Scand J Trauma Resusc Emerg Med 2009, 17:45.

33. Nystrup KB, Windelov NA, Thomsen AB, Johansson PI: Reduced clot strength upon admission, evaluated by thrombelastography (TEG), in trauma patients is independently associated with increased 30-day mortality. Scand J Trauma Resusc Emerg Med 2011, 19:52.

34. Schochl H, Maegele M, Solomon C, Gorlinger K, Voelckel W: Early and individualized goal-directed therapy for trauma-induced coagulopathy. Scand J Trauma Resusc Emerg Med 2012, 20:15

35. Lier H, Krep H, Schroeder S, Stuber F: Preconditions of hemostasis in trauma: a review. The influence of acidosis, hypocalcemia, anemia, and hypothermia on functional hemostasis in trauma. J Trauma 2008, 65:951-960.

36. Brohi K, Singh J, Heron M, Coats T: Acute traumatic coagulopathy. J Trauma 2003, 54:1127-1130

37. Brohi K, Cohen MJ, Davenport RA: Acute coagulopathy of trauma: mechanism, identification and effect. Curr Opin Crit Care 2007. 13:680-685

38. Brohi K, Cohen MJ, Ganter MT, Matthay MA, Mackersie RC, Pittet JF: Acute traumatic coagulopathy: initiated by hypoperfusion: modulated through the protein C pathway? Ann Surg 2007, 245:812-818.

39. Brohi K, Cohen MJ, Ganter MT, Schultz MJ, Levi M, Mackersie RC, Pittet JF: Acute coagulopathy of trauma: hypoperfusion induces systemic anticoagulation and hyperfibrinolysis. J Trauma 2008, 64:1211-1217. discussion 1217

40. Engels PT, Rezende-Neto JB, Al Mahroos M, Scarpelini S, Rizoli SB, Tien HC The natural history of trauma-related coagulopathy: implications for treatment. J Trauma 2011, 71:S448-S455.

41. Johansson PI, Stensballe J, Rasmussen LS, Ostrowski SR: High circulating adrenaline levels at admission predict increased mortality after trauma. J Trauma 2011, 72:428-436.

42. Eddy VA, Morris JA Jr: Cullinane DC: Hypothermia, coagulopathy, and acidosis. Surg Clin North Am 2000, 80:845-854

43. Holcomb JB, Jenkins D, Rhee P, Johannigman J, Mahoney P, Mehta S, Cox ED, Gehrke MJ, Beilman GJ, Schreiber M, Flaherty SF, Grathwohl KW, Spinella 
PC, Perkins JG, Beekley AC, McMullin NR, Park MS, Gonzalez EA, Wade CE, Dubick MA, Schwab CW, Moore FA, Champion HR, Hoyt DB, Hess JR: Damage control resuscitation: directly addressing the early coagulopathy of trauma. J Trauma 2007, 62:307-310.

44. Beekley AC: Damage control resuscitation: a sensible approach to the exsanguinating surgical patient. Crit Care Med 2008, 36:S267-S274.

45. Dawes R, Thomas GO: Battlefield resuscitation. Curr Opin Crit Care 2009, 15:527-535.

46. Cotton BA, Au BK, Nunez TC, Gunter OL, Robertson AM, Young PP: Predefined massive transfusion protocols are associated with a reduction in organ failure and postinjury complications. J Trauma 2009, 66:41-48. discussion 48-9.

47. Duchesne JC, McSwain NE Jr, Cotton BA, Hunt JP, Dellavolpe J, Lafaro K, Marr AB, Gonzalez EA, Phelan HA, Bilski T, Greiffenstein P, Barbeau JM, Rennie KV, Baker CC, Brohi K, Jenkins DH, Rotondo M: Damage control resuscitation: the new face of damage control. J Trauma 2010, 69:976-990.

48. Gonzalez EA, Moore FA, Holcomb JB, Miller CC, Kozar RA, Todd SR, Cocanour CS, Balldin BC, McKinley BA: Fresh frozen plasma should be given earlier to patients requiring massive transfusion. J Trauma 2007 62:112-119.

49. Nascimento B, Callum J, Rubenfeld G, Neto JB, Lin Y, Rizoli S: Clinical review: Fresh frozen plasma in massive bleedings - more questions than answers. Crit Care 2010, 14:202.

50. Dunbar NM, Chandler WL: Thrombin generation in trauma patients. Transfusion 2009, 49:2652-2660.

51. Holland $L L$, Brooks JP: Toward rational fresh frozen plasma transfusion: The effect of plasma transfusion on coagulation test results. Am J Clin Pathol 2006, 126:133-139.

52. Karkouti K, Levy JH: Commentary: recombinant activated factor VII: the controversial conundrum regarding its off-label use. Anesth Analg 2011, 113:711-712.

53. Hoffman M, Monroe DM 3rd: The action of high-dose factor VIla (FVIla) in a cell-based model of hemostasis. Dis Mon 2003, 49:14-21.

54. Yank V, Tuohy CV, Logan AC, Bravata DM, Staudenmayer K, Eisenhut R, Sundaram V, McMahon D, Olkin I, McDonald KM, Owens DK, Stafford RS: Systematic review: benefits and harms of in-hospital use of recombinant factor VIla for off-label indications. Ann Intern Med 2011, 152:529-540.

55. Stein DM, Dutton RP, O'Connor J, Alexander M, Scalea TM: Determinants of futility of administration of recombinant factor VIla in trauma. J Trauma 2005, 59:609-615.

56. Schochl H, Frietsch T, Pavelka M, Jambor C: Hyperfibrinolysis after major trauma: differential diagnosis of lysis patterns and prognostic value of thrombelastometry. J Trauma 2009, 67:125-131.

57. Theusinger OM, Wanner GA, Emmert MY, Billeter A, Eismon J, Seifert B, Simmen HP, Spahn DR, Baulig W: Hyperfibrinolysis diagnosed by rotational thromboelastometry (ROTEM) is associated with higher mortality in patients with severe trauma. Anesth Analg 2011, 113:1003-1012.

58. CRASH-2 trial collaborators, Shakur H, Roberts I, Bautista R, Caballero J, Coats T, Dewan Y, El-Sayed H, Gogichaishvili T, Gupta S, Herrera J, Hunt B, Iribhogbe $\mathrm{P}$, Izurieta M, Khamis H, Komolafe E, Marrero MA, Mejia-Mantilla J, Miranda J, Morales C, Olaomi O, Olldashi F, Perel P, Peto R, Ramana PV, Ravi RR, Yutthakasemsunt S: Effects of tranexamic acid on death, vascular occlusive events, and blood transfusion in trauma patients with significant haemorrhage (CRASH-2): a randomised, placebo-controlled trial. Lancet 2010, 376:23-32.

59. CRASH-2 collaborators, Roberts I, Shakur H, Afolabi A, Brohi K, Coats T, Dewan Y, Gando S, Guyatt G, Hunt BJ, Morales C, Perel P, Prieto-Merino $D$, Woolley $T$ : The importance of early treatment with tranexamic acid in bleeding trauma patients: an exploratory analysis of the CRASH-2 randomised controlled trial. Lancet 2011, 377:1096-1101. 1101.e1-2.

60. Knudson MM, Collins JA, Goodman SB, McCrory DW: Thromboembolism following multiple trauma. J Trauma 1992, 32:2-11.

61. Hardy JF, De Moerloose P, Samama M: Groupe d'interet en Hemostase Perioperatoire: Massive transfusion and coagulopathy: pathophysiology and implications for clinical management. Can J Anaesth 2004, 51:293-310

62. Blow O, Magliore L, Claridge JA, Butler K, Young JS: The golden hour and the silver day: detection and correction of occult hypoperfusion within
24 hours improves outcome from major trauma. J Trauma 1999, 47:964-969.

63. Boldt J: Do plasma substitutes have additional properties beyond correcting volume deficits? Shock 2006, 25:103-116.

64. Cabrales $P$, Tsai AG, Intaglietta M: Is resuscitation from hemorrhagic shock limited by blood oxygen-carrying capacity or blood viscosity? Shock 2007, 27:380-389.

65. Boldt J, Ince C: The impact of fluid therapy on microcirculation and tissue oxygenation in hypovolemic patients: a review. Intensive Care Med 2010, 36:1299-1308.

66. Rhee $\mathrm{P}$, Koustova $\mathrm{E}$, Alam HB: Searching for the optimal resuscitation method: recommendations for the initial fluid resuscitation of combat casualties. J Trauma 2003, 54:S52-S62.

67. Alam HB, Rhee P: New developments in fluid resuscitation. Surg Clin North Am 2007, 87:55-72. vi.

68. De Backer D, Donadello K, Taccone FS, Ospina-Tascon G, Salgado D, Vincent $\mathrm{J}$ : Microcirculatory alterations: potential mechanisms and implications for therapy. Ann Intensive Care 2011, 1:27.

69. Pieracci FM, Biffl WL, Moore EE: Current concepts in resuscitation. J Intensive Care Med 2011, 27:79-96.

70. Ertmer C, Kampmeier T, Rehberg S, Lange M: Fluid resuscitation in multiple trauma patients. Curr Opin Anaesthesiol 2011, 24:202-208.

71. Antonelli M, Levy M, Andrews PJ, Chastre J, Hudson LD, Manthous C, Meduri GU, Moreno RP, Putensen C, Stewart T, Torres A: Hemodynamic monitoring in shock and implications for management. International Consensus Conference, Paris, France, 27-28 April 2006. Intensive Care Med 2007, 33:575-590.

72. Abou-Khalil B, Scalea TM, Trooskin SZ, Henry SM, Hitchcock R: Hemodynamic responses to shock in young trauma patients: need for invasive monitoring. Crit Care Med 1994, 22:633-639.

73. Scalea TM, Maltz S, Yelon J, Trooskin SZ, Duncan AO, Sclafani SJ: Resuscitation of multiple trauma and head injury: role of crystalloid fluids and inotropes. Crit Care Med 1994, 22:1610-1615.

74. Abramson D, Scalea TM, Hitchcock R, Trooskin SZ, Henry SM, Greenspan J: Lactate clearance and survival following injury. J Trauma 1993, 35:584-588. discussion 588-9.

75. McNelis J, Marini CP, Jurkiewicz A, Szomstein S, Simms HH, Ritter G, Nathan IM: Prolonged lactate clearance is associated with increased mortality in the surgical intensive care unit. Am J Surg 2001, 182:481-485.

76. Meregalli A, Oliveira RP, Friedman G: Occult hypoperfusion is associated with increased mortality in hemodynamically stable, high-risk, surgical patients. Crit Care 2004, 8:R60-R65.

77. Husain FA, Martin MJ, Mullenix PS, Steele SR, Elliott DC: Serum lactate and base deficit as predictors of mortality and morbidity. Am J Surg 2003, 185:485-491.

78. Jansen TC, van Bommel J, Schoonderbeek FJ, Sleeswijk Visser SJ, van der Klooster JM, Lima AP, Willemsen SP, Bakker J: LACTATE study group: Early lactate-guided therapy in intensive care unit patients: a multicenter, open-label, randomized controlled trial. Am J Respir Crit Care Med 2010, 182:752-761.

79. Bland RD, Shoemaker WC, Abraham E, Cobo JC: Hemodynamic and oxygen transport patterns in surviving and nonsurviving postoperative patients. Crit Care Med 1985, 13:85-90.

80. Shoemaker WC, Appel PL, Kram HB, Waxman K, Lee TS: Prospective trial of supranormal values of survivors as therapeutic goals in high-risk surgical patients. Chest 1988, 94:1176-1186.

81. Fleming A, Bishop M, Shoemaker W, Appel P, Sufficool W, Kuvhenguwha A Kennedy F, Wo CJ: Prospective trial of supranormal values as goals of resuscitation in severe trauma. Arch Surg 1992, 127:1175-1179. discussion $1179-81$.

82. Bishop MH, Shoemaker WC, Appel PL, Wo CJ, Zwick C, Kram HB, Meade P, Kennedy F, Fleming AW: Relationship between supranormal circulatory values, time delays, and outcome in severely traumatized patients. Crit Care Med 1993, 21:56-63.

83. Boyd O, Grounds RM, Bennett ED: A randomized clinical trial of the effect of deliberate perioperative increase of oxygen delivery on mortality in high-risk surgical patients. JAMA 1993, 270:2699-2707.

84. Hayes MA, Yau EH, Timmins AC, Hinds CJ, Watson D: Response of critically ill patients to treatment aimed at achieving supranormal oxygen delivery and consumption. Relationship to outcome. Chest 1993, 103:886-895. 
85. Bishop MH, Shoemaker WC, Appel PL, Meade P, Ordog GJ, Wasserberger J, Wo CJ, Rimle DA, Kram HB, Umali R: Prospective, randomized trial of survivor values of cardiac index, oxygen delivery, and oxygen consumption as resuscitation endpoints in severe trauma. J Trauma 1995, 38:780-787.

86. Velmahos GC, Demetriades D, Shoemaker WC, Chan LS, Tatevossian R, Wo CC, Vassiliu P, Cornwell EE 3rd, Murray JA, Roth B, Belzberg H, Asensio JA, Berne TV: Endpoints of resuscitation of critically injured patients: normal or supranormal? A prospective randomized trial. Ann Surg 2000, 232:409-418.

87. Gattinoni L, Brazzi L, Pelosi P, Latini R, Tognoni G, Pesenti A, Fumagalli R: A trial of goal-oriented hemodynamic therapy in critically ill patients. SvO2 Collaborative Group. N Engl J Med 1995, 333:1025-1032.

88. Durham RM, Neunaber K, Mazuski JE, Shapiro MJ, Baue AE: The use of oxygen consumption and delivery as endpoints for resuscitation in critically ill patients. J Trauma 1996, 41:32-39. discussion 39-40.

89. Heyland DK, Cook DJ, King D, Kernerman P, Brun-Buisson C: Maximizing oxygen delivery in critically ill patients: a methodologic appraisal of the evidence. Crit Care Med 1996, 24:517-524.

90. McKinley BA, Kozar RA, Cocanour CS, Valdivia A, Sailors RM, Ware DN, Moore FA: Normal versus supranormal oxygen delivery goals in shock resuscitation: the response is the same. J Trauma 2002, 53:825-832.

91. Balogh Z, McKinley BA, Cocanour CS, Kozar RA, Valdivia A, Sailors RM, Moore FA: Supranormal trauma resuscitation causes more cases of abdominal compartment syndrome. Arch Surg 2003, 138:637-642. discussion 642-3.

92. Tisherman SA, Barie P, Bokhari F, Bonadies J, Daley B, Diebel L, Eachempati SR, Kurek S, Luchette F, Carlos Puyana J, Schreiber M, Simon R: Clinical practice guideline: endpoints of resuscitation. J Trauma 2004, 57:898-912.

93. Porter JM, Ivatury RR: In search of the optimal end points of resuscitation in trauma patients: a review. J Trauma 1998, 44:908-914.

94. Marik PE: The optimal endpoint of resuscitation in trauma patients. Crit Care 2003, 7:19-20.

95. Bilkovski RN, Rivers EP, Horst HM: Targeted resuscitation strategies after injury. Curr Opin Crit Care 2004, 10:529-538.

96. Johnson JL, Moore EE, Kashuk JL, Banerjee A, Cothren CC, Biffl WL, Sauaia A: Effect of blood products transfusion on the development of postinjury multiple organ failure. Arch Surg 2010, 145:973-977.

97. Chang MC, Mondy JS, Meredith JW, Holcroft JW: Redefining cardiovascular performance during resuscitation: ventricular stroke work, power, and the pressure-volume diagram. J Trauma 1998, 45:470-478.

98. Chang MC, Meredith JW, Kincaid EH, Miller PR: Maintaining survivors' values of left ventricular power output during shock resuscitation: a prospective pilot study. J Trauma 2000, 49:26-33. discussion 34-7.

99. Chang MC, Martin RS, Scherer LA, Meredith JW: Improving ventricular-arterial coupling during resuscitation from shock: effects on cardiovascular function and systemic perfusion. J Trauma 2002, 53:679-685.

100. Trzeciak S, Rivers EP: Clinical manifestations of disordered microcirculatory perfusion in severe sepsis. Crit Care 2005, 9(Suppl 4):S20-S26.

101. De Backer D, Ortiz JA, Salgado D: Coupling microcirculation to systemic hemodynamics. Curr Opin Crit Care 2010, 16:250-254.

102. De Backer D, Donadello K, Favory R: Link between coagulation abnormalities and microcirculatory dysfunction in critically ill patients. Curr Opin Anaesthesiol 2009, 22:150-154.

103. De Backer D, Creteur J, Dubois MJ, Sakr Y, Koch M, Verdant C, Vincent JL: The effects of dobutamine on microcirculatory alterations in patients with septic shock are independent of its systemic effects. Crit Care Med 2006, 34:403-408

104. Dubin A, Pozo MO, Casabella CA, Palizas F Jr, Murias G, Moseinco MC, Kanoore Edul VS, Palizas F, Estenssoro E, Ince C: Increasing arterial blood pressure with norepinephrine does not improve microcirculatory blood flow: a prospective study. Crit Care 2009, 13:R92.

105. Jhanji S, Lee C, Watson D, Hinds C, Pearse RM: Microvascular flow and tissue oxygenation after major abdominal surgery: association with post-operative complications. Intensive Care Med 2009, 35:671-677.

106. Bergstrom MF, Byberg L, Melhus $H$, Michaelsson K, Gedeborg R: Extent and consequences of misclassified injury diagnoses in a national hospital discharge registry. Inj Prev 2011, 17:108-113.

107. Konstantinidis A, Inaba K, Dubose J, Barmparas G, Talving P, David JS, Lam L, Demetriades $D$ : The impact of nontherapeutic hypothermia on outcomes after severe traumatic brain injury. J Trauma 2011, 71:1627-1631.
108. Kheirbek T, Kochanek AR, Alam HB: Hypothermia in bleeding trauma: a friend or a foe? Scand J Trauma Resusc Emerg Med 2009, 17:65.

109. Gentilello LM, Jurkovich GJ, Stark MS, Hassantash SA, O'Keefe GE: Is hypothermia in the victim of major trauma protective or harmful? A randomized, prospective study. Ann Surg 1997, 226:439-447. discussion 447-9.

110. Jurkovich GJ, Greiser WB, Luterman A, Curreri PW: Hypothermia in trauma victims: an ominous predictor of survival. J Trauma 1987, 27:1019-1024.

111. Inaba K, Teixeira PG, Rhee P, Brown C, Salim A, DuBose J, Chan LS, Demetriades D: Mortality impact of hypothermia after cavitary explorations in trauma. World J Surg 2009, 33:864-869.

112. Arthurs Z, Cuadrado D, Beekley A, Grathwohl K, Perkins J, Rush R, Sebesta J: The impact of hypothermia on trauma care at the 31st combat support hospital. Am J Surg 2006, 191:610-614.

113. Beilman GJ, Blondet JJ, Nelson TR, Nathens AB, Moore FA, Rhee P, Puyana JC, Moore EE, Cohn SM: Early hypothermia in severely injured trauma patients is a significant risk factor for multiple organ dysfunction syndrome but not mortality. Ann Surg 2009, 249:845-850.

114. Valeri CR, Feingold H, Cassidy G, Ragno G, Khuri S, Altschule MD: Hypothermia-induced reversible platelet dysfunction. Ann Surg 1987, 205:175-181.

115. Harris OA, Colford JM Jr, Good MC, Matz PG: The role of hypothermia in the management of severe brain injury: a meta-analysis. Arch Neurol 2002, 59:1077-1083.

116. Kempainen RR, Brunette DD: The evaluation and management of accidental hypothermia. Respir Care 2004, 49:192-205.

117. Bernard SA, Gray TW, Buist MD, Jones BM, Silvester W, Gutteridge G, Smith $\mathrm{K}$ : Treatment of comatose survivors of out-of-hospital cardiac arrest with induced hypothermia. N Engl J Med 2002, 346:557-563.

118. Kurz A, Sessler DI, Lenhardt R: Perioperative normothermia to reduce the incidence of surgical-wound infection and shorten hospitalization. Study of Wound Infection and Temperature Group. N Engl J Med 1996, 334:1209-1215.

119. Seamon MJ, Wobb J, Gaughan JP, Kulp H, Kamel I, Dempsey DT: The effects of intraoperative hypothermia on surgical site infection: an analysis of 524 trauma laparotomies. Ann Surg 2012, 255:789-795.

120. Thorsen K, Ringdal KG, Strand K, Soreide E, Hagemo J, Soreide K: Clinical and cellular effects of hypothermia, acidosis and coagulopathy in major injury. Br J Surg 2011, 98:894-907

121. Holness L, Knippen MA, Simmons L, Lachenbruch PA: Fatalities caused by TRALI. Transfus Med Rev 2004, 18:184-188.

122. Skeate RC, Eastlund T: Distinguishing between transfusion related acute lung injury and transfusion associated circulatory overload. Curr Opin Hematol 2007, 14:682-687.

123. Vamvakas EC, Blajchman MA: Blood still kills: six strategies to further reduce allogeneic blood transfusion-related mortality. Transfus Med Rev 2010, 24:77-124.

124. Bernard GR, Artigas A, Brigham KL, Carlet J, Falke K, Hudson L, Lamy M, LeGall JR, Morris A, Spragg R: Report of the American-European Consensus conference on acute respiratory distress syndrome: definitions, mechanisms, relevant outcomes, and clinical trial coordination.Consensus Committee. J Crit Care 1994, 9:72-81.

125. Vamvakas EC, Blajchman MA: Transfusion-related immunomodulation (TRIM): an update. Blood Rev 2007, 21:327-348.

126. Bux J, Sachs UJ: The pathogenesis of transfusion-related acute lung injury (TRALI). Br J Haematol 2007, 136:788-799.

127. Rana R, Fernandez-Perez ER, Khan SA, Rana S, Winters JL, Lesnick TG, Moore SB, Gajic O: Transfusion-related acute lung injury and pulmonary edema in critically ill patients: a retrospective study. Transfusion 2006, 46:1478-1483.

128. Gajic O, Rana R, Winters JL, Yilmaz M, Mendez JL, Rickman OB, O'Byrne MM, Evenson LK, Malinchoc M, DeGoey SR, Afessa B, Hubmayr RD, Moore SB: Transfusion-related acute lung injury in the critically ill: prospective nested case-control study. Am J Respir Crit Care Med 2007, 176:886-891.

129. Watson GA, Sperry JL, Rosengart MR, Minei JP, Harbrecht BG, Moore EE, Cuschieri J, Maier RV, Billiar TR, Peitzman AB: Inflammation and Host Response to Injury Investigators: Fresh frozen plasma is independently associated with a higher risk of multiple organ failure and acute respiratory distress syndrome. J Trauma 2009, 67:221-227. discussion 228-30. 
130. Gong MN, Thompson BT, Williams P, Pothier L, Boyce PD, Christiani DC: Clinical predictors of and mortality in acute respiratory distress syndrome: potential role of red cell transfusion. Crit Care Med 2005, 33:1191-1198.

131. Benson AB, Moss M, Silliman CC: Transfusion-related acute lung injury (TRALI): a clinical review with emphasis on the critically ill. Br I Haematol 2009, 147:431-443.

132. Inaba K, Branco BC, Rhee P, Holcomb JB, Blackbourne LH, Shulman I, Nelson J, Demetriades D: Impact of ABO-identical vs ABO-compatible nonidentical plasma transfusion in trauma patients. Arch Surg 2010, 145:899-906.

133. Popovsky MA: Transfusion-associated circulatory overload: the plot thickens. Transfusion 2009, 49:2-4.

134. Narick C, Triulzi DJ, Yazer MH: Transfusion-associated circulatory overload after plasma transfusion. Transfusion 2012, 52:160-165.

135. Hendrickson JE, Hillyer CD: Noninfectious serious hazards of transfusion. Anesth Analg 2009, 108:759-769.

136. Huerta-Alardin AL, Varon J, Marik PE: Bench-to-bedside review: Rhabdomyolysis - an overview for clinicians. Crit Care 2005, 9:158-169.

137. Ward MM: Factors predictive of acute renal failure in rhabdomyolysis. Arch Intern Med 1988, 148:1553-1557.

138. Better OS, Rubinstein I: Management of shock and acute renal failure in casualties suffering from the crush syndrome. Ren Fail 1997, 19:647-653.

139. Ronquist G, Waldenstrom A: Imbalance of plasma membrane ion leak and pump relationship as a new aetiological basis of certain disease states. J Intern Med 2003, 254:517-526.

140. Smith HM, Farrow SJ, Ackerman JD, Stubbs JR, Sprung J: Cardiac arrests associated with hyperkalemia during red blood cell transfusion: a case series. Anesth Analg 2008, 106:1062-1069. table of contents.

141. Cheatham ML: Abdominal compartment syndrome: pathophysiology and definitions. Scand J Trauma Resusc Emerg Med 2009, 17:10.

142. Malbrain ML, Cheatham ML, Kirkpatrick A, Sugrue M, Parr M, De Waele J, Balogh Z, Leppaniemi A, Olvera C, Ivatury R, D'Amours S, Wendon J, Hillman K, Johansson K, Kolkman K, Wilmer A: Results from the International Conference of Experts on Intra-abdominal Hypertension and Abdominal Compartment Syndrome. I. Definitions. Intensive Care Med 2006 32:1722-1732.

143. Mohmand H, Goldfarb S: Renal dysfunction associated with intraabdominal hypertension and the abdominal compartment syndrome. J Am Soc Nephrol 2011, 22:615-621.

144. Balogh ZJ, Leppaniemi A: Patient populations at risk for intra-abdominal hypertension and abdominal compartment syndrome. Am Surg 2011, 77(Suppl 1):S12-S16.

145. Balogh ZJ, Malbrain M: Resuscitation in intra-abdominal hypertension and abdominal compartment syndrome. Am Surg 2011, 77(Suppl 1):S31-S33.

146. Barnes GE, Laine GA, Giam PY, Smith EE, Granger HJ: Cardiovascular responses to elevation of intra-abdominal hydrostatic pressure. Am J Physiol 1985, 248:R208-R213.

147. Scalea TM, Bochicchio GV, Habashi N, McCunn M, Shih D, McQuillan K, Aarabi B: Increased intra-abdominal, intrathoracic, and intracranial pressure after severe brain injury: multiple compartment syndrome. J Trauma 2007, 62:647-656. discussion 656.

148. Sugrue M, Bauman A, Jones F, Bishop G, Flabouris A, Parr M, Stewart A, Hillman K, Deane SA: Clinical examination is an inaccurate predictor of intraabdominal pressure. World I Surg 2002, 26:1428-1431.

149. Leppaniemi A: Surgical management of abdominal compartment syndrome; indications and techniques. Scand I Trauma Resusc Emerg Med 2009, 17:17.

150. DuBose JJ, Scalea TM: Glucose elevations and outcome in critically injured trauma patients. Adv Surg 2011, 45:187-196.

151. Eriksson EA, Christianson DA, Vanderkolk WE, Bonnell BW, Hoogeboom JE, Ott MM: Tight blood glucose control in trauma patients: Who really benefits? J Emerg Trauma Shock 2011, 4:359-364.

152. Collier B, Diaz J Jr, Forbes R, Morris J Jr, May A, Guy J, Ozdas A, Dupont W, Miller $R$, Jensen $G$ : The impact of a normoglycemic management protocol on clinical outcomes in the trauma intensive care unit. JPEN J Parenter Enteral Nutr 2005, 29:353-358. discussion 359.

153. Rushing GD, Britt RC, Collins JN, Cole FJ, Weireter L, Britt LD: Adrenal insufficiency in hemorrhagic shock. Am Surg 2006, 72:552-554.

154. Ho HC, Chapital AD, Yu M: Hypothyroidism and adrenal insufficiency in sepsis and hemorrhagic shock. Arch Surg 2004, 139:1199-1203.
155. Roquilly A, Mahe PJ, Seguin P, Guitton C, Floch H, Tellier AC, Merson L, Renard B, Malledant Y, Flet L, Sebille V, Volteau C, Masson D, Nguyen JM, Lejus C, Asehnoune $\mathrm{K}$ : Hydrocortisone therapy for patients with multiple trauma: the randomized controlled HYPOLYTE study. JAMA 2011, 305:1201-1209.

156. Edwards P, Arango M, Balica L, Cottingham R, El-Sayed H, Farrell B, Fernandes J, Gogichaisvili T, Golden N, Hartzenberg B, Husain M, Ulloa MI, Jerbi Z, Khamis H, Komolafe E, Laloe V, Lomas G, Ludwig S, Mazairac G, Munoz Sanchez Mde L, Nasi L, Olldashi F, Plunkett P, Roberts I, Sandercock P, Shakur H, Soler C, Stocker R, Svoboda P, Trenkler S, Venkataramana NK, Wasserberg J, Yates D, Yutthakasemsunt S, CRASH trial collaborators: Final results of MRC CRASH, a randomised placebo-controlled trial of intravenous corticosteroid in adults with head injury-outcomes at 6 months. Lancet 2005, 365:1957-1959.

157. Stack G, Baril L, Napychank P, Snyder EL: Cytokine generation in stored, white cell-reduced, and bacterially contaminated units of red cells. Transfusion 1995, 35:199-203.

158. Tinmouth A, Fergusson D, Yee IC, Hebert PC, ABLE Investigators, Canadian Critical Care Trials Group: Clinical consequences of red cell storage in the critically ill. Transfusion 2006, 46:2014-2027.

159. Vandromme MJ, McGwin G Jr, Weinberg JA: Blood transfusion in the critically ill: does storage age matter? Scand I Trauma Resusc Emerg Med 2009, 17:35.

160. Machiedo GW, Zaets SB, Berezina TL, Xu DZ, Feketova E, Spolarics Z, Deitch EA: Trauma-hemorrhagic shock-induced red blood cell damage leads to decreased microcirculatory blood flow. Crit Care Med 2009, 37:1000-1010.

161. Weinberg JA, McGwin G Jr, Griffin RL, Huynh VQ, Cherry SA 3rd, Marques $M B$, Reiff DA, Kerby JD, Rue LW 3rd: Age of transfused blood: an independent predictor of mortality despite universal leukoreduction. J Trauma 2008, 65:279-282. discussion 282-4.

162. Weinberg JA, McGwin G Jr, Vandromme MJ, Marques MB, Melton SM, Reiff $D A$, Kerby JD, Rue LW 3rd: Duration of red cell storage influences mortality after trauma. J Trauma 2010, 69:1427-1431. discussion 1431-2.

163. Zallen G, Offner PJ, Moore EE, Blackwell J, Ciesla DJ, Gabriel J, Denny C, Silliman CC: Age of transfused blood is an independent risk factor for postinjury multiple organ failure. Am J Surg 1999, 178:570-572.

doi:10.1186/1757-7241-20-68

Cite this article as: Shere-Wolfe et al: Critical care considerations in the management of the trauma patient following initial resuscitation. Scandinavian Journal of Trauma, Resuscitation and Emergency Medicine 2012 20:68.

\section{Submit your next manuscript to BioMed Central and take full advantage of:}

- Convenient online submission

- Thorough peer review

- No space constraints or color figure charges

- Immediate publication on acceptance

- Inclusion in PubMed, CAS, Scopus and Google Scholar

- Research which is freely available for redistribution 